811.163.41'367.622

811.163.41'342.8

https://doi.org/10.18485/sj.2021.26.1.34

СТЕФАН М. СТЕПАНОВИЪ *

Институт за српски језик САНУ

Београд
Оригинални научни рад

Примљен: 13. 10. 2020.

Прихваћен: 12. 1. 2021.

\title{
АКЦЕНАТ ИМЕНИЦЕ СВЕТЛО
}

У раду се анализира акценат именице светло. Циљ истраживања је да се дође до закључка који би нам показао које акценатско решење има највише оправдања да буде део књижевнојезичке акценатске норме. Акценатска проблематика ове именице биће осветљена из 5 углова: из творбено-фонолошког угла; из дијахронијског угла; из угла језика добрих ијекавских писаца; из угла стања у српским дијалектима и из угла досадашњег стања у речницима и правописима српског језика.

Кључне речи: српски језик, акцентологија, дијахронија, дијалектологија, именица светло, књижевни језик.

1. Увод. Тема рада је акценат именице светло. Одлучили смо се за бављење овом проблематиком пошто смо приметили да је најновија ситуација у књижевнојезичкој норми таква да није у сагласју са већином говора из најуже основице, али и са решењима из појединих нормативних гласила двадесетог века.

О акценту именице светло писало се и раније. Историја тог проблема почиње са радовима Алије Наметка (1955) и Асима Пеце (1955), где су оба

*stefan.stepanovic@isj.sanu.ac.rs

** Овај рад финансирало је Министарство просвете, науке и технолошког развоја Републике Србије према Уговору број 451-03-68/2020-14/200174, који је склопљен са Институтом за српски језик САНУ. 
аутора као централни проблем својих радова имали дилему да ли је исправан ијекавски облик свјетло или свијетло; дакле, да ли именица светло у ијекавским говорима има једносложан или двосложан рефлекс јата (акценат им није био централна тема рада).

Наш циљ је да осветлимо акценат именице светло из више углова и тиме увидимо који (екавски и ијекавски) облик највише заслужује да буде део књижевнојезичке норме. Прво, осветлићемо акценат именице из угла дијахроније; друго и треће, као и Асим Пецо (idem.), приказаћемо стање у појединим српским говорима, али не само ијекавским, већ и екавским, и стање у језику писаца са ијекавског говорног подручја; четврто, приказаћемо ситуацију у речницима и правописима српског (и српскохрватског) језика; пето, настојаћемо да проблем осветлимо и са творбено-фонолошког становишта.

2. ТвОРБЕНО-ФОНОЛОШКо СТАНОВИшТЕ. Именица светло је настала поименичавањем, што се констатује и у РЈАЗУ у оквиру одреднице свијетло. Овим поглављем смо настојали да осветлимо акценатску проблематику ове именице и са творбено-фонолошког гледишта. Наиме, циљ нам је био да увидимо акценатско понашање речи насталих поименичавањем према њиховим мотивним речима, да нађемо типичан акценатски однос и да видимо какав бисмо акценат са становишта таквог односа могли да очекујемо и код поменуте именице.

Будући да је конверзија од свих типова творбе речи најмање плодна у српском језику (Клајн 2003: 379), јасно је да нема превише примера које бисмо могли да анализирамо, па су нам грађу чинили првенствено примери из Клајнове Творбе речи у савременом српском језику (2. део) (2003), али и примери из друге коришћене литературе.

Може се направити разлика између две групе именица које настају поименичавањем. ${ }^{1}$ Прва група је далеко доминантнија и у њу спадају именице које су настале од неког облика придева у одређеном виду. Неки од примера

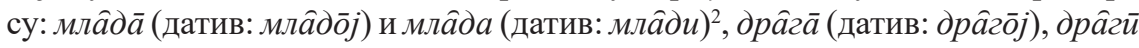

\footnotetext{
${ }^{1}$ Ми ћемо акценат заједничких именица наводити углавном према РСЈ.

${ }^{2}$ Парадигма млаิда-млаิди показује да ова именица постаје скоро у потпуности поименичена, свакако више него друге заједничке именице женског и мушког рода (не рачунајући именице васиона, запета, ујна и стрина). Разлог за то је највероватније одређено семантичко разилажење са мотивним придевом. Како Станимир Ракић истиче (2002/2003: 198-199) именица млада је вероватно настала у народу онда када су се скоро само младе жене удавале, а временом су се обичаји и услови живота променили, те данас млада уопште не мора бити млада особа. Вероватно нешто слично важи и за именице ујна и стрина, које су синхронијски изгубиле везу са мотивним придевима (а и са именицама од којих су ти присвојни придеви настали: $y j$ и стриј (РЈАЗУ)), јер они не постоје, бар не у већини говора, колико нам је познато, те стога имају потпуну именичку промену. Именица млада је настала од одређеног вида, а то потврђује акценат у српском језику (в. Маројевић 2005: 771) (исто потврђује и словачки, у ком ова именица познаје дужину на последњем слогу (mladá) и има придевску промену кроз парадигму, али то у овом
} 


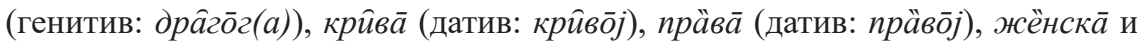

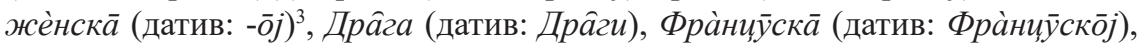

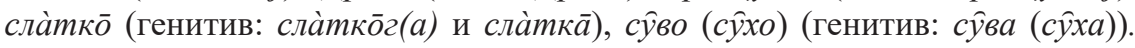
Осим акцента номинатива, на настанак од придева одређеног вида указује и деклинација новонасталих именица, која је истоветна придевској из одређеног вида, што акценатски, што морфолошки. Изузетак су поједина женска властита имена, која имају именичку промену и не познају дужину у номинативу, а њихов акценат сугерише да су настале од одређеног вида. ${ }^{4}$

У другу групу би спадале именице настале од неодређеног вида: доббро злӧо, блаิго ${ }^{7}{ }^{8}$ Примећујемо да у ову групу спадају само именице средњег рода

случају није сметало да постане потпуно поименичена, баш због губљења везе са мотивним придевом, а потврду оваквог понашања нам можда дају и неки говори које наводи Александар Белић (2006: 257), а који познају именице ујна и стрина са остацима придевске промене (уjној, стриној). Могуће да ти говори познају и мотивне придеве за ове именице.

Семантичко разилажење мотивног придева и именице настале поименичавањем свакако је присутно и у случају именица васиона и запета.

${ }^{3}$ Дублетан акценат има и придев (жѐнски, $-\bar{a},-\bar{o}$ и жёнски, $\left.-\bar{a},-\bar{o}\right)$.

${ }^{4}$ Како Клајн истиче (Клајн 2003: 380), женска имена типа Јасна, Дивна, Драга, Лепа, Мила, Тијана и сл. представљају можда једине примере поименичених придева са несумњивом именичком променом. Међутим, Радмило Маројевић (2005: 770) критикује тај став напомињући да многе од тих именица нису ни настале од придева, а оне које јесу у источнохерцеговачким говорима познају дужину у номинативу једнине и придевску деклинацију у осталим падежима (нпр. Мйла (Мйло̄j) и Драิга (Драิгōj).

${ }^{5}$ Осим што имамо пример 'Добро се добрим враћа', који наводи Клајн (2003: 380) и којим указује да именица доббро у том значењу има инструментал по придевској промени, док у значењу 'земљишни посед, имање' има инструментал по именичкој промени, у РСАНУ смо видели и пример који гласи 'Добро се добром враћа', а и у свим осталим примерима именица је имала именичку промену (невезано за значење), тако да је спорадичан облик придевске промене занемарљив, нарочито ако се види колико се именица акценатски, фонетски (облик са непостојаним А у генитиву множине и са дугоузлазним акцентом на другом слогу) и морфолошки поклапа са именицама средњег рода. Према томе је јасно да ова именица нема различите инструментале у односу на значење.

Неке од потврда ове именице у словенским језицима су: dobro, -а (чешки и словачки), dobro, -ega (словеначки), добро, -а (руски).

${ }^{6}$ Неке од потврда у словенским језицима cy: zlo, -a (чешки и словачки), zlo, -a (словеначки), зло, -а (руски).

${ }^{7}$ Именица блаิго је сачувала акценат старијег акценатског облика придева (блаิго) (о акценту овог придева в. Белић 1914: 11-15).

${ }^{8}$ Да су ове именице настале од облика придева у неодређеном виду, указује нам првенствено акценат у српском језику (и одсуство дужине на задњем слогу у чешком и словачком). Може се рећи да су се оне, ако имамо на уму њихову флексију, потпуно поименичиле (и у другим словенским језицима: нпр. имамо прецизне потврде да је тако у словачком). Разлог за то може бити што су те именице средњег рода настале од неодређеног вида придева у средњем роду, који се флексијом и не разликује много од флексије именица средњег рода, те је пут поименичавању у овом случају био олакшан. Доказ томе је и да практично немамо потпуно поименичене именице мушког и женског рода, пошто оне најчешће настају од флексијски доста различитог (у односу на именице) одређеног вида придева. Међутим, ту долазимо и до другог битног момента. Наиме, поменуте именице средњег рода су шире заступљене у словенским језицима, те 
(наравно, настале од облика придева у средњем роду). Видимо да је доста мање тих именица, што је у складу са тврдњом Александра Белића (2006: 256) да су придеви одређеног вида после свог развијања у општесловенском језику преузели на себе функцију „супстантивизирања”, али и са тврдњом Милорада Дешића (2000: 348-349) да се придеви ретко налазе у именичкој служби у неодређеном виду и да се углавном поименичавају придеви у одређеном виду.

Посебну напомену заслужују именице које се акценатски разликују од мотивног придева. То су нпр. именице рйметн, цёвеен, зёлерн и сл.. Сматрамо да у тим случајевима долази до изражаја и њихова припадност одређеној кате-

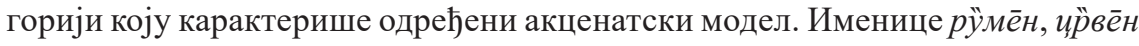
и зёлеен облички су се поклопиле са именицама мушког рода типа $n \ddot{p} с т \bar{e} н$, $\ddot{y ə z љ е т н ~ и ~ с л . ~ и ~ т и м е ~ с у ~ м о г л е ~ д о б и т и ~ њ и х о в ~ а к ц е н а т . ~ У ~ п и т а њ у ~ ј е ~ т е н д е н ц и ј а ~}$ при уобличавању акценатских облика коју спомиње Јелица Јокановић Михајлов (2012: 88-89) - тенденција која настоји да превлада деривациони моменат услед ког се речи уобличавају на начин који ће истицати њихове лексичке специфичности.

Овим је јасно да се поименичавањем често задржава акценат мотивне речи при настанку именица, а да само посебни услови онемогућују то акценатско задржавање.

После свега, јасно је да би се акценатски облик све́тло уврстио у групу именица насталих од неодређеног вида придева. Придев светао у неодређеном виду данас гласи: светтао и све́тао, све́тла, све́тло, а у одређеном виду: све̂тлй-светлла̄-све̂тло̄. Ту додајемо да је придев светао дијахронијски припадао акценатском типу који је у оквиру неодређеног вида имао дугосилазни акценат у мушком и средњем роду, а дугоузлазни у женском роду (свётао-све́тла-све̂тло), што ћемо поткрепити у дијахронијском делу. Да је ова именица настала од облика придева у неодређеном виду, указује нам акценат у српском језику (и одсуство дужине у чешком и словачком, што имају придеви одређеног вида (неодређени није ни сачуван) и именице настале од њих), али и остали разлози које смо навели код осталих именица које су настале од неодређеног вида придева. Ова именица је шире заступљена у словенским језицима, те је

су највероватније део прасловенског лексичког фонда, што нам показује и чињеница да су често у словенским језицима (за словачки смо имали увид у целу парадигму, а за остале језике само генитив) у којима се јављају у идентичном облику као краћи облик придева у средњем роду оне заправо потпуно поименичене (не рачунајући словеначки), јер да су настале од одређеног вида, то би се сигурно сачувало у језицима у неком трагу, као што је то био случај са именицом млада, за коју би се такође рекло да је део прасловенског фонда. То нам говори да дуг временски период од настанка речи до данас није пресудан за потпуно поименичавање, већ настанак од неодређеног вида (за именице средњег рода) и слабљење везе између именице и мотивног придева (за именице женског рода). Нешто слично тврди и Јелена Лепојевић (2014: 106), која истиче да промена супстантивата зависи од вида мотивног придева, где ће именице настале од придева одређеног вида имати придевску промену, а оне настале од придева неодређеног вида - именичку. 
и она највероватније део прасловенског лексичког фонда. ${ }^{9}$ Именица светло је, дакле, свакако настала и пре поменутих акценатских модификација придева, и то доста пре, али пошто није изгубила значајнију семантичку везу са придевом, прошла је кроз исту акценатску модификацију као њен мотивни придев и није „окаменила” стари акценат, што се на пример није десило са прилозима, али нпр. и именицом благо, која се семантички удаљила од придева, ${ }^{10}$ те је сачувала акценат некадашњег акценатског облика неодређеног вида.

\section{3. ДИЈАХРОНИЈСКО СТАНОВИШТЕ.}

Оно што одмах видимо на основу места акцента у руском и украјинском, где срећемо акценат на првом слогу, то је да у српском језику, а у њему је акценат на истом слогу, изворан акценат мора бити силазан. Потврде из словенских језика су нпр.: све́тло (руски), сві́тло (украјински), světlo (чешки), svetlo (словачки).

Вокал који се среће на слогу под акцентом је рефлекс некадашњег јата. Битно је истаћи да је јат по пореклу дуг вокал, тако да је са тог становишта у прасловенском на том слогу могао стајати само акценат који је карактеристичан за дуге слогове. Три акцента су у прасловенском могла бити на тим слоговима, а то су: стари акут, дуги циркумфлекс и дуги неоакут (Каповић 2015: 71-79).

У чешком и словачком имамо рефлексе кратког јата, а имајући у виду да ова два језика дужину чувају на слогу са дугим неоакутом (Каповић 2015: 77), јасно је да тај акценат није постојао у овој речи. Као коначно решење нам остаје стари акут или дуги циркумфлекс. Облик свётло са краткоузлазним акцентом на проклитици (на̀ светло) (али и са краткосилазним акцентом кроз целу парадигму (осим понекад аналошких узлазних акцената у номинативу и генитиву множине, прим. аут.) указује да би такав облик по пореклу имао стари акут (Каповић: 2011: 113). Ипак, такво тумачење не би имало смисла

${ }^{9}$ Како Рајна Драгићевић тврди (2018: 15-16), то што нека лексема има потврду у већини словенских језика, не мора да значи да је она обавезно прасловенског порекла, већ је могла настати и касније у сваком језику понаособ. Ако имамо у виду да већ од најранијих времена имамо продирање одређеног вида у наше споменике и да су се неке промене у вези са видовима извршиле још у доисторијско време (Белић 2006: 245-246), а имајући у виду да је српски језик сачувао неодређени вид у некој мери и да га многи словенски језици немају, али имају потпуно поименичене поменуте именице средњег рода, можемо претпоставити да су те именице средњег рода и настале у прасловенско време и од неодређеног вида, и то рано - пре ширења одређеног вида.

${ }^{10}$ У РСАНУ се види да овај придев најчешће и примарно значи неке духовне особине, а тек каснија и секундарнија значења региструју неку материјалност ('трошност (нпр. камена)', 'ненагризност (нпр. метала)'), а именица блаิго се у српском од свих словенских језика можда и највише удаљила од те придевске семантике (в. ЕССЯ 2: 173), те се, како нам показује РСАНУ, највише односи на материјално ('новац', 'већа количина злата', 'иметак', 'имовина', 'стока'...), а веома мало на духовно ('духовне', 'културне вредности', 'добро', 'срећа'...). 
ни када би ова именица настала извођењем од прасловенске именице * světъ. $^{11}$ Божидар Финка (1977: 117-118) истиче да и именице на -ло имају понекад акценатска скраћења у односу на мотивне речи, а именицу светло у једном моменту и тумачи као насталу суфиксацијом. ${ }^{12}$ Међутим, пошто је именица настала конверзијом, на шта указује и словеначки, који ту именицу нема, али има придев у именичкој функцији где се поклапа са значењем ове именице у осталим словенским језицима у којима се среће, онда очекујемо исти акценат као у придеву од ког је настала, а не акценат који се квантитативно (из данашње перспективе и квалитативно) разликује од придевског. Практично је немогуће да суфиксацијом од именице * světъ $^{13}$ добијемо именицу истог значења, кад већ суфикси уносе промену у значењу, а такође и за сам суфикс -ло је карактеристично да се додаје на глаголске основе, тј. именице на -ло као мотивне речи имају у принципу само глаголе, судећи према великој већини примера у Обрайном речнику (изузетак може бити именица стиойало). Овако би се могло рећи да краткосилазни акценат може представљати резултат аналогије према акценту именице свётло̄сm, како тврди Далибор Брозовић (1956: 151).

Облик свётло је највероватније прелазна етапа између облика све́тло и облика свѐтло и највероватније је настао аналогијом према акценту именице свётло̄сm, која се у великој мери семантички поклапа са именицом светло. Баш та блискост је и била неопходан услов таквој аналогији, будући да сличан аналошки утицај немамо у случају именица блаิго и блӓго̄ $c m$, које нису ни близу толико семантички блиске, па у крајњем случају ни код пара све̂ст : свёсно̄ст.

Придев све́тао, све́тла, све́тло као старије и изворније стање, што смо већ помињали, у српском језику би имао следеће облике: светтао-све́mла-свеิтло, што потврђује и Решетар са својим материјалом из говора који чувају старије стање код придева (1900: $114-115),{ }^{14}$ а исто и данашњи акценат

${ }^{11}$ Тада би краткосилазни акценат био очекиван, будући да би именица *světъlo као вишесложница могла имати скраћење акцента из именице *světъ и даље припадност акценатској парадигми Ц, за коју је, како Мате Каповић истиче (2015: 249), карактеристичан дуги циркумфлекс, а потврду краћења тог акцента даје вишесложни номинатив множине те именице (свё $\bar{u} о в и)$. За дуги циркумфлекс су карактеристична краћења у вишесложним речима (нпр. $c \hat{u} н>$ сйнови; млаิд>млӓдо̄cm) (в. Каповић 2015: 238-239). Уколико би била тумачена ова именица као припадница акценатске парадигме А (као што се тумачи у Каповић 2011: 113), онда би се стари акут очекивао једино на суфиксу, ако имамо у виду (према Каповић 2015: 98-102) да се од облика акценатске парадигме Ц може добити стари акут на суфиксу ако је он доминантан (са становишта валентности), те према томе не бисмо данас имали краткосилазни акценат на основи, већ краткоузлазни, који је данашња норма и прихватила.

${ }^{12}$ Аутор је овом тврдњом оправдавао облик свётло (Финка 1977: 117-118).

${ }^{13}$ Потврде за значење именице *světъ налазимо у РЈАЗУ, а такође и у руском језику, где је она доминантнија од именице светло, која у руском има покрајински карактер.

${ }^{14}$ У случају овог придева, дубровачки говор не чува старије стање, већ има следећу парадигму: свйјетао, свијѐтло (Решетар 1900: 114-115), иако је он познат као један од штокавских говора који најбоље чувају старије акценатско стање код придева (в. нпр. Белић 1914: 13-15). 
прилога светло ${ }^{15}$, а место акцента и квалитет нам потврђује и руски са својим краћим облицима (све́mел, светла́, све́тло) ${ }^{16}$. Узгред, именица свётло̄сm, која је настала од истог придева, својим краћењем дугог акцента из придева приликом њеног настанка указује да је акценат у придеву по пореклу дуги циркумфлекс. Онда би се облик свеิтло очекивао као изворни и за именицу, а он је заједно са придевом временом доживео заједничку промену акцента, пошто су сачували семантичку везу, што смо већ истакли. Могуће да нам на исту природу акцента именице као у придеву (тј. да је (дуги) циркумфлекс) указује и то што акценат прелази на проклитику испред именице светло у руском, ${ }^{17}$ како видимо у речнику Ушакова, у ком смо једино видели потврде за ову именицу, која ни у Ушаковљево време није била карактеристична за књижевни језик, већ за дијалекат, а акценат јој је био на првом слогу.

Облик свѐтло може бити резултат акценатске аналогије према множинским облицима који су се могли срести за ову именицу када је у номинативу једнине имала краткосилазни акценат. У српском језику постоје такве именице средњег рода које имају краткосилазни акценат у падежима једнине, али се он мења у (кратко ${ }^{18}$ )узлазне акценте у падежима множине (нпр. бр̈до (ном. мн. бр̀да), звӧно (звоेна) и др.) (Стевановић 1991: 129-130). За именицу светло заиста и постоје потврде са узлазним акцентом у множини, ${ }^{19}$ али они нису доминантни; истина у питању је хрватски језик, а потврде су из Прапатница у Вргорској крајини (свѝтла) (Каповић 2011: 113), ${ }^{20}$ мада је свакако упитно колико су могли ти падежи у множини акценатски утицати на падеже у једнини, пошто се код именица средњег рода које квалитативно имају различите акценте

${ }^{15}$ Већ смо истицали да се у прилозима насталим од придева чува стари акценат неодређеног вида. Овде прилог гласи и све̂тло и све́тло. Дакле, приметно је да и у прилог продире дугоузлазни акценат (који је већ захватио и све облике неодређеног вида придева).

${ }^{16}$ Овакво стање у руском срећемо у Ушаковљевом речнику, који је старији речник и представља лексику пре Другог светског рата, а већ у новом ортоепском речнику из 2017 (Большой орфоэпический словарь) (Јелена Гинић: писмено саопштење), али и у Аваносовљевом ортоепском речнику, акценат краћег облика придева у средњем роду налази се на наставку (светло́), што нам указује да је акценатски облик са акцентом на основи застарео, а то већ потврђује ортоепски речник Ирине Леонидовне Резниченко, који облик са акцентом на основи и квалификује као застарели.

17 За циркумфлекс (дуги и кратки) карактеристично је да акценат који је његов одраз у руском прелази на проклитику (Каповић 2015: 74).

${ }^{18}$ У генитиву множине среће се дугоузлазни акценат (нпр. бр́д̄), који се у именицама са непостојаним А помера на други слог (нпр. клуба́ка̄, маса́ла̄) (Стевановић 1991: 129-130).

${ }^{19}$ Само 2 информатора која су имала краткосилазни акценат у номинативу једнине упитали смо и за акценат множине и увидели смо да у генитиву множине имају акценатски облик све-

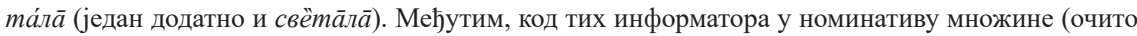
је тако и у осталим множинским падежима) срели смо само краткосилазни акценат из једнине.

${ }^{20}$ Мате Каповић (2010: 100) истиче да се у генитиву множине у хрватском језику среће и аналошки облик свјета́ла̄. Такав акценат смо и ми сретали код наших информатора са ијекавског простора, што смо већ истакли. 
у једнини и множини акценат једнине показао доминантнијим, те је он утицао на акценат множине, ${ }^{21}$ али није непостојећи ни обрнути смер аналогије. ${ }^{22}$ Такви множински акценатски облици (посебно генитив множине, будући да је он чешће предмет аналогије (номинатив множине доста ређе)) могли су утицати на акценатски прилазак именицама које у номинативу имају краткоузлазни акценат. За те именице (нпр. вѐсло, сѐдло, ста̀кло) је карактеристичан дугоузлазни акценат на непостојаном А у генитиву множине (Стевановић 1991: 131-132). Таквих именица (судећи по Обратном речнику) има нешто више од оних двосложних са завршетком сугласник + -ло (дакле, са непостојаним А) и познатије су просечном говорнику, те свакако у свим тим чињеницама може лежати узрок краткоузлазног акцента у именици свѐтло. Очигледно је иста аналогија и у именици гесло, која у РСАНУ, РМС, РСЈ и Обратном речнику има и облик са краткосилазним акцентом (који је ту изворан) и облик са краткоузлазним.

4. ДИЈАЛЕКАТСКО СТАНОВИШТЕ У СРПСКОМ ЈЕЗИКУ. За ПОтребе истражИвања спровели смо једну дијалектолошку анкету у којој смо имали информаторе са различитих терена где се говори српски језик, и то од Далмације на западу до источне Србије на истоку, и од Новог Сада на северу до области Дробњака на југу. Укупно смо имали четрдесетак информатора. Настојали смо да увидимо које су акценатске варијанте чешће међу говорницима српског језика, а такође и да ли поједине варијанте посебно карактеришу неке говорне типове.

Двосложну ијекавску замену јата Алија Наметак уопште није срео у Босни и Херцеговини, како сам истиче (1955: 81), али је Асим Пецо (1955: 156) напоменуо да је обишао читаву Херцеговину и да је двосложну замену срео у следећим местима: Рабина (Невесиње), Борач, Наданићи (Гацко), Ластва (Требиње), Дабар (Столац), а ван Херцеговине у Никшићу, Дробњаку и код јекаваца на Златибору. Придодајмо овде и податке до којих је дошао Далибор Брозовић (1956: 151), који истиче да је облик свијетло, и то са дугоузлазним акцентом (свије́тло), чуо у Бањанима, Крешеву (као варијанту свие́тло), док је у Задарском, Имотском и Сињском котару чуо икавски облик са дугоузлазним акцентом (сви́тло). Свјётло се среће у Славонији (РЈАЗУ, међу примерима).

Наши подаци су слични, што се тиче ијекавских говора. Напоменућемо да је ијекавски облик свијетло од источнохерцеговачких говора најзаступљенији у говорима Црногорске Херцеговине, али и црногорским говорима уопште (не само источнохерцеговачким). Тако је у Никшићу, Даниловграду, па и у Подгорици (Милан Ивановић: писмено саопштење). Исте податке имамо и из

${ }^{21}$ Тако РСАНУ нпр. за именицу брдо у номинативу и генитиву множине поред облика

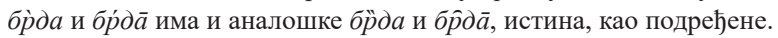

${ }^{22}$ Тако према изворној парадигми ја̄je (ном. мн. jája) и иревво (ире́ва) данас у књижевном језику имамо jáje (jája) и uре́во (ире́ва), што важи и за хрватски језик (в. Каповић 2011: 130). 
Горње Бијеле код Шавника (Дробњак). Свјетло је најдоминантније у источнохерцеговачим говорима Босне и Херцеговине, што западним (Бања Лука, Богдаши, Ливањско Поље), што у источнијим (Гацко, Требиње, Сарајево), док у српским говорима у Хрватској срећемо и облик свјетло (Бенковац) и облик свијетло (Биовичино Село (Кистање)). Код свих потврда облик свјетло смо сретали само са краткосилазним акцентом (свјётло).

Што се тиче акцента екавског облика именице светло, дугоузлазни акценат се среће у великом делу западне Србије, али и источније, у неким косовско-ресавским говорима. Прецизније речено, што се тиче шумадијско-војвођанских говора, овај акценатски облик је карактеристичан за шумадијске говоре овог говорног типа, али и за поједине косовско-ресавске говоре који су ближи шумадијским говорима (потврде из Врњачке Бање, Опарића, Великог Поповића). Такође, исти акценатски облик је карактеристичан и за источнохерцеговачке говоре у западној Србији (Пожега, Драгачево 23 , Ужице, Ивањица). У колубарском говору је то најдоминантнији акценатски облик, у горњомилановачком говору такође. Потврду за све́тло имамо и у севернијим говорима (Ушће (Обреновац)). Већ у мачванском и сремском говору срећемо облик са краткосилазним акцентом (у сремском доста ређе и облик са краткоузлазним). Тако је и у говору Новог Сада (свётло). Облик свётло се среће и у Београду (доста ређе и свѐтло), Панчеву. У војвођанским говорима литература (Речник српских говора Војводине) потврђује равномерно и облик свётло и све́тло (Петровић и др. 2008: 78).

Овим смо показали колико је заправо присутан облик све́тло на екавском подручју и да никако не може бити тачна тврдња Јована Вуковића (1949: 19) да тај облик не постоји на екавском терену; штавише, он је најдоминантнији у оним екавским говорима који су у основици књижевног језика, од којих је већина, што се акценатске норме тиче, и у најужој основици.

На крају ове дијалекатске анализе можемо као неку врсту другог дела закључка овог поглавља цитирати Далибора Брозовића: „Oblik svijetlo nije dakle tako rijedak, i ne može se nešto, što je zabilježeno u Bosni, Dalmaciji, Hercegovini, Crnoj Gori i Srbiji, označiti ,pokrajinskim” izgovorom” (1956: 151).

5. СТАНОВИШТЕ ЈЕЗИКА ИЈЕКАВСКИХ ПИСАЦА. Већ сМО У УВОДУ ИстаКЛИ Да је ово критеријум који је испитивао и Асим Пецо у својим разматрањима (1955), и то узимајући у обзир грађу за РСАНУ ${ }^{24}$. Одлучили смо се и ми да погледамо грађу за РСАНУ, у овом случају само за именицу полусветло, с обзиром на то да ова реч није била захваћена Пециним разматрањима. За именицу светло ексцерпирали смо дела из дигиталне едиције Антологија српске књижевно-

${ }^{23}$ Поред нашег информатора, да је за Драгачево карактеристичан акценатски лик све́тло, потврђује и Речник Драгачева (Петровић 2019: 504).

24 За скраћенице видети 20. том Речника. 
сти са сајта Учитељског факултета Београдског универзитета, а такође смо користили и Електронски корпус Душка Витаса.

Из приложеног материјала Асима Пеце (idem.: 156-157) јасно је да облик са двосложном заменом јата срећемо највише код хрватских писаца, ${ }^{25}$ што је показала и грађа РСАНУ за именицу полусветло. Анализом друге поменуте грађе увидели смо да се тај облик (од наших писаца) доследно јавља и код Владана Деснице. Асим Пецо (1955: 156-157) је на основу анализиране грађе за РСАНУ увидео да има писаца који користе и облик свјетло и облик свијетло, а један од њих је и Иво Ћипико (поред хрватских писаца). Додајемо да је то, од српских писаца, и Иво Андрић. Свеукупно, за српске писце карактеристичнији је облик свјетло.

\section{ПОЛУСВИЈЕТЛО}

Хладно полусвијетло (Нех. 2, 24); блиједо полусвијетло (Хирц 1, 13); полумрака и полусвијетла (Чер. 1, 130); полусвијетлу измичућега дана (Драж. 2, 12); благом полусвијетлу (Крањч. С. 6, 154);

\section{ПОЛУСВЈЕТЛО}

захуканим полусвјетлом (Леск. 1, 86); тајинственост њезина полусвјетла (Ђал. $2,116)$; полусвјетло задњег сунчанога трака (Војн. И. 1, 107); ружичасто полусвјетло (Селим. 5, 61); сјена [се] полусвјетлом пење (Алауп. 1, 136);

\section{СВЈЕТЛО}

блиједим свјетлом (Ћипико, За крухом, 136); заигра свјетло (Ћопић, Чаробна шума, $231)^{26}$; свјетло је било угашено (Милићевић, Беспуће, 36); расте ... | свјетло (М. Тешић, У тесном склопу, 92); свјетло све јављајет еја (М. Лесковац, Старија српска поезија, 38 (Орфелин, Мелодија к пролећу)); треба изнијети на свјетло (К. Николић, Тито говори ..., ЕК); трошкови за гријање, свјетло и воду (Б. Билбија, Основи библиотекарства, ЕК); одијели ... свјетло од таме (Д. Киш, Складиште, ЕК); свјетло трне (Е. А. По (превео Б. Недић), Уговорени састанак, ЕК); упалио [је] свјетла (П. Симић, Светац и магле..., ЕК); запале се свјетла (Андрић, Ћоркан и Швабица, ЕК);

СВИЈЕТЛО

видим ... | свијетло (Ћопић, Чаробна шума, 121); ни ... свијетла [нема] (Десница, Прољећа Ивана Галеба, 272); упали свијетло (Р. Трифковић, Себичност, ЕК); сунчевог свијетла (Ј. Поповић, Правни системи ..., ЕК); у свијетлу ... разлике (Д. Киш, Ното poeticus, EK).

6. СТАНОВИШТЕ СТАњА У РЕЧНИЦИМА. ОНо Што је први Утисак, имајући у виду стање у досадашњим речницима и правописима српског језика, то је велико занемаривање акценатског облика са дугоузлазним акцентом за екавско наречје и његовог ијекавског еквивалента са двосложним рефлексом јата. Занемаривање поменутих облика је толико да се они чак не препоручују ни као подређени члан могућег дублетног пара, већ им је у потпуности дат

\footnotetext{
${ }^{25}$ Грађа за РСАНУ је показала да је и Иво Андрић користио облик свијетло (Пецо 1955: 156).

${ }^{26}$ У овом делу Бранка Ћопића више је потврда са једносложним рефлексом јата него са двосложним.
} 
скрајнут и искључиво дијалекатски карактер. Тако Правописни речник из 1960, РСЈ и РМС наводе само облик свѐтло (ијекавски: свјѐтло). Алија Наметак (1955: 81-82) даје податке из Белићевог Правописа српскохрватског књижевног језика (свјётло), Боранићевог Правописа хрватскога или српскога језика (свијетло), Ристић-Кангргиног Речника српскохрватског и немачког језика (свѐтло), Вуковићевог Правописа савременог намег језика (свјётло) и Броз-Ивековићевог Рјечника хрватскога језика (свијетло). Свјётло је једино прихваћено у Речнику (и)јекавизама српског језика.

Изузетак представљају РЈАЗУ и Обратни речник српскога језика, али ни у њима не налазимо иста акценатска решења, а ни исти статус акценатског облика са дугоузлазним акцентом, тј. његовог ијекавског еквивалента. Наиме, РЈАЗУ наводи само облик свијетло (не и свјетло). У Обратном речнику српског језика срећемо акценатске облике све́тло и свијѐтло, али као доста подређене облицима свѐтло и свјѐтло, што нам сугерише то да нису стављени само на друго место, већ и у заграду.

Овакво занемаривање акценатског облика све́тло, а једино прихватање облика свѐтло у нашој новијој речничкој и правописној традицији могло би и да сугерише да се облик са дугоузлазним акцентом доживљава као некакав резултат кановачког дуљења.

Тај облик свакако није резултат кановачког дуљења, ако се уопште сматра тиме, и то не само зато што се већином среће и на територији где тог дуљења нема, већ и зато што је добио акценат од мотивног придева на основу очекиваног и природног акценатског процеса приликом конверзије.

7. ЗАКљУчАК. На основу увида у свих пет обрађених аспеката, можемо рећи да акценатски облик све́тло (свијѐтло) није био са правом изостављан из књижевнојезичке акценатске норме, будући да се у нашем истраживању показао најоправданијим. Наиме, такав облик је очекиван са становишта најтипичнијег акценатског односа између мотивног придева и мотивисане именице приликом поименичавања (како је поменута именица и настала), који подразумева да су мотивна и мотивисана реч најчешће акценатски идентичне. Такође, овај облик има и одређених дијахронијских оправдања, а вредно је истаћи да, иако није најфреквентнији у српским говорима, најфреквентнији је у великом броју говора који су у најужој основици књижевног језика. Потпуно супротна ситуација је са акценатским обликом свѐтло, који у новије време представља једини облик који је део књижевнојезичке акценатске норме, а на основу аспеката са којих смо посматрали ову појаву, можемо рећи да је то и најмање оправдани облик. Облик свётло (свјётло) је негде на средини, те би свакако могао, бар у некаквом статусу, да се поново прихвати као део норме, што је и био до половине прошлог века, а то је акценатски облик који се најчешће среће у српским говорима. 


\section{ЛИТЕРАТУРА}

АСК: Антологија српске къижевности, (http://www.antologijasrpskeknjizevnosti.rs/).

Белић 1914: А. Белић, Акиенатске студије I, Београд: СКА.

Белић 2006: А. Белић, Историја српског језика, Београд: Завод за уџбенике и наставна средства.

Брозовић 1956: D. Brozović, Jezična i pravopisna pitanja o jatu, Jezik: časopis za kulturu hrvatskoga književnog jezika, 5/5, 147-153.

Вуковић 1949: Ј. Вуковић, Правописна правила и упутства за писање ијекавских гласовних облика са правописним рјечником ијекавизама, Сарајево: Свјетлост.

ГрРСАНУ: Грађа за израду Речника српскохрватског књижевног и народног језика САНУ.

Дешић 2000: М. Дешић, Српски акценат и полисемија, Јужнословенски филолог, LVI/1-2, 343-355.

Драгићевић 2018: Р. Драгићевић, Српска лексика у прошлости и данас, Нови Сад: Матица српска.

ЕК: Електронски корпус, (http://www.korpus.matf.bg.ac.rs/prezentacija/korpus.html).

Јокановић Михајлов 2012: Ј. Јокановић-Михајлов, Прозодија и говорна кулmура, Београд: Друштво за српски језик и књижевност Србије.

Каповић 2010: M. Kapović, Naglasak o-osnova muškoga roda u hrvatskom povijesni razvoj, Filologija : časopis Razreda za filološke znanosti Hrvatske akademije znanosti i umjetnosti, 54, 51-109.

Каповић 2011: M. Kapović, Naglasak imenica srednjeg roda u hrvatskom - povijesni razvoj, Hrvatski dijalektološki zbornik, 17, 109-146.

Каповић 2015: M. Kapović, Povijest hrvatske akcentuacije. Fonetika, Zagreb: Matica hrvatska.

Клајн 2003: И. Клајн, Творба речи у савременом српском језику. Други део. Суфиксаиија и конверзија, Београд: Завод за уџбенике и наставна средства.

Лепојевић 2014: Ј. Лепојевић, Супстантивизација као творбени процес и именице неименичких деклинација у руском и српском језику [докторска дисертација], Београд: Филолошки факултет.

Маројевић 2005: Р. Маројевић, Творба речи у савременом српском језику Ивана Клајна (1), Српски језик, X, 658-779. 
Наметак 1955: A. Nametak, Svjetlo ili svijetlo?, Jezik: časopis za kulturu hrvatskoga književnog jezika, 4/3, 81-82.

Николић 2000: М. Николић, Обратни речник српскога језика, Нови Сад - Београд: Матица српска - Институт за српски језик САНУ - Палчић.

ОСРЯ 1: Р. Иванович Аванесов, Орфоэпический словарь русского язы$\kappa a$, (https://povto.ru/russkie/slovari/orfoepicheskie/avanesov/ orfoepicheskij-avanesov-1988_0021.htm).

ОСРЯ 2: И. Леонидовна Резниченко, Орфоэпический словарь русского языка Произношение. Ударение, (https://povto.ru/russkie/slovari/ orfoepicheskie/reznichenko/orfoepicheskij-slovar-reznichenko_0017. $\mathrm{htm})$.

Остојић/Вујичић 2000: Б. Остојић, Д. Вујичић, Речник (и)јекавизама српског језика, Подгорица: ЦИД.

Петровић и др. 2008: Д. Петровић, С. Вареника, Д. Милорадов, К. Сунајко, И. Црњак, С. Радојчић, Речник српских говора Војводине, св. 8, Нови Сад: Матица српска - Тиски цвет.

Петровић/Капустина 2019: Д. Петровић, Ј. Капустина, Речник Драгачева, Српски дијалектолошки зборник, 66/2, 7-635.

Пецо 1955: A. Peco, Svjetlo ili svijetlo?, Jezik: časopis za kulturu hrvatskoga književnog jezika, 4/5, 155-157.

Правопис 1960: Правопис српскохрватскога књижевног језика : са правописним речником, Нови Сад - Загреб: Матица српска - Матица хрватска.

Ракић 2002-2003: С. Ракић, О проблему конверзије придева у именице. Наш језик, XXXIV/3-4, 195-208.

Решетар 1900: M. Rešetar, Die serbokroatische Betonung südwestlicher Mundarten, Wien: Alfred Hölder, K. u K. Hof- und Universitäts-Buchhandler.

PJA3У: Rječnik hrvatskoga ili srpskoga jezika, I-XXIII, Zagreb: JAZU.

PMC: Речник српскохрватскога књижевног језика, I-VI, Нови Сад: Матица српска.

РСАНУ: Речник српскохрватског књижевног и народног језика, 1-20, Београд: САНУ - Институт за српски језик САНУ.

PCJ 2011: Речник српскога језика, Нови Сад: Матица српска.

CP: Slovački rečnici, (http://slovniky.korpus.sk/).

CСКJ: Slovar slovenskega knjižnega jezika, (http://bos.zrc-sazu.si/sskj.html). 
Стевановић 1991: М. Стевановић, Кюига о акиенту књижевног језика, Београд: Завод за уџбенике и наставна средства.

ТСРЯ: Д. Николаевич Ушаков, Толковый словарь русского языка, (https:// kartaslov.ru/значение-слова/светло).

Финка 1977: B. Finka, Svjetlo ili svijetlo, Jezik: časopis za kulturu hrvatskoga književnog jezika, 25/4, 117-118.

YP: Češki rečnik, (http://ssjc.ujc.cas.cz/search.php).

ЭССЯ: Этимологический словарь славянских языков, 1-, Москва: Наука.

\section{THE ACCENT OF SERBIAN SVETLO 'LIGHT'}

\section{Summary}

This paper deals with the accent of the noun svetlo 'light'. The aim of the research was to reach a conclusion that would show us which accent solution has the most justification for being part of the standard Serbian language. Accent of this noun is illuminated with 5 aspects: aspects of the science of word formation, a diachronic aspects, aspects of the language of good writers from ijekavian area, aspects of situation in Serbian dialects and from the point of view of Serbian dictionaries and ortographies. The accent form све́тло (свијѐтло) has proven to be the most justifiable, especially with aspect of the science of word formation. Also, it is justified from the dialectological and diachronic aspects, and somewhat less from the aspects of the language of good ijekavian writers. The accent form свётло (свјётло) is the most widespread, but it was also most often part of the norm in the first half of the last century. The accent form свѐтло (свјѐтло) is at least justified by the viewpoints we have examined, except that it is only form in the new accent norm.

Key words: Serbian language, accentology, dialectology, noun light, standard language. 